\title{
NEPHROTOXICITY IN RABBITS FOLLOWING SUBCHRONIC EXPOSURE TO NIGERIAN CRUDE OILL
}

\author{
OVURU, S.S., ORUWARI, B.M. AND BEREPUBO, N.A. \\ Department of Animal Science, Rivers State University of Science \\ and Technology, P.M.B. 5080, Port Harcourt, Nigeria.
}

\section{SUMMARY}

Nephrotoxicity in rabbits following subchronic exposure to crude oil was studied. The exposure levels were w/w $0.00 \%, 0.05 \%, 0.10 \%, 0.15 \%$ and $0.20 \%$. The graded doses were included in their diets. Serum from experimental animals was assayed for indicators of kidney function. The parameters were alkaline phosphatase, urea, creatinine, glucose, total protein and albumin. All the biochemical indicators increased significantly $(P<0.05)$ with increasing concentration of crude oil. Morphologically, a marked reduction in size of the kidneys was observed. The mean weight of the kidneys in the control was $11.41 \mathrm{~g} \pm 0.84$ and decreased from $9.31 \mathrm{~g} \pm 0.25$ to $6.47 \mathrm{~g}+0.55$ with increasing dietary concentration of crude oil. Histological examination revealed that there were eosinophilic casts in the lumen of the distal convoluted tubules. The Bowmans capsule was dilated and contain some loose eosinophilic casts. Eosinophilia was also observed in some sections of the kidneys. It is concluded that crude oil is nephrotoxic in rabbits and may probably result to kidney failure.

\section{INTRODUCTION}

Environmental exposure of both marine and terrestrial animals to xenobiotics can result in sublethal effects (Carls, et al., 1999; Ngodigha et al., 1999; Carls et al., 2000). These may include biochemical alterations, immunological and indeed an array of physiological impairment. Within the Niger Delta region, the absence of any systematic long-term research on the content and effects of crude oil in organisms is a serious lacuna in that it is now impossible to judge the actual state of pollution of the environment with petroleum hydrocarbons. Yet, this region is the richest in oil mineral resources, shellfish, finfish and has an extensive mangrove swamp and other forest reserves as well as human population (Imevbore, 1979). This valuable ecosystem is, however vulnerable to destruction by petroleum and petroleum related products due to the fact that the oil industry operational activities are concentrated within this zone (Imevbore and Adeyemi, 1981, Snowden and Ekweozor, 1987).

Various components of crude oil are taken up and bioaccu mulate in tissues with concentrations much higher than the surrounding environment (Payne et al., 1988; Thomas et al; 1989). Most marine and terrestrial animals receive hydrocarbons from their food and water sources and this represent the major route of contamination and uptake.

Pollutants such as petroleum hydrocarbons alter the growth of pelagic fish (Vignier et $a l .$, 1992). The same petroleum hydrocarbons in polluted urban sediments have been closely correlated with alterations in detoxification enzymes (Vignier et al., 1992), tissue abnormalities (Mc Cain et al., 1978) and reproductive hormones (Truscott et al., 1992). Unfortunately, the correlation of many of these cellular biomarkers with changes in kidney tissues is unknown. 


\section{NIGERIAN VETERINARY JOURNAL}

The main objective of this work was to determine if twelve weeks of exposure to crude oil would significantly affect kidney functions and alterations in rabbits. The choice of rabbits for this study was predicated upon the fact that they are known to feed on forage in the wild just like their counterparts, the grasscutter. These animals could therefore be prone to crude oil contamination should any spillage occur within the vicinity of their habitat. The results can be used to determine the potential pathological effects of hydrocarbon exposure under field conditions.

\section{MATERIALS AND METHODS}

Thirty-two (32) rabbits of known pedigree aged 20-22 weeks, mean weight $1.26 \mathrm{~kg}$ were procured from Rivers State Ministry of Agriculture and Natural Resources. They were housed in conventional hutches made of local materials (bamboo) at the Teaching and Research Farm, Rivers State University of Science and Technology, Port Harcourt and pre-conditioned for two weeks. During pre-conditioning, they were given coccidiostat (25\% of embazin) and broadspectrum antibiotics (teramycin). Their feed was prepared from grass and legumes and supplemented with concentrate (growers mash) from Pfizer (Nig.) Plc. Drinking and feeding troughs were cleaned and kept hygienically from preconditioning to the end of the study period.

Crude oil was obtained from the Bonny Terminal and allowed to weather after being exposed in shallow pans to sunlight for $24 \mathrm{hrs}$ in order to allow the volatile fractions to vaporize thus simulating the naturally occurring fraction during spillage (Neff, et al., 2000). Measured (w/w) amount of weathered crude oil was incorporated into the forage/hay mix and poultry feed by standard methods according to Sastry and Thomas (1981).

Thirty rabbits of both sexes were randomly assigned into batches of six to five dietary groups in two blocks of varying dose levels as follows:

Group I: $0.00 \%$ w/w (No contamination control)

Group II: $0.05 \%$ w/w Crude Oil Contamination Group III: $0.10 \%$ w/w

Group IV: $0.15 \% \mathrm{w} / \mathrm{w}$

Group V: $0.20 \% \mathrm{w} / \mathrm{w}$

The animals were starved for $24 \mathrm{hrs}$ before being introduced to the experimental diets. The experiment lasted 90 days. Feed and water were served ad-libitum.

At the end of the 90day period, blood samples were obtained from two bucks and two does from each of the treatment groups by cardiac puncture with a sterile disposable syringe and needle. About $10 \mathrm{ml}$ blood was transferred into EDTA fortified tubes, labeled and centrifuged. Serum was then harvested, into plastic tubes and stored at $-20^{\circ} \mathrm{C}$ until ready for analysis. Analyses were completed within 7 days of collection. Alkaline phosphatase (ALP) was determined according to the procedures of the German Society of Clinical Chemistry (Hafkensheid and Kohler, 1986). Serum urea was quantified with the ureaseglutamic dehydrogenase reaction (Eisenweiner, 1976), creatinine was measured by the Jaffe reaction at $500 \mathrm{~nm}$ (Fabiny and Ertinghausen, 1971). Glucose was determined according to Bendar and Mead (1974). Total protein concentration in serum was measured using the biuret reaction (Doumas, 1975) while Albumin was determined with the Bromocresol Green (BCG) method. 
Furthermore, the animals whose blood samples were taken were slaughtered and autopsied immediately. The kidneys were obtained and fixed in $10 \%$ neutral buffered formalin and embedded in paraffin wax. The fixed tissues were sectioned to about $6 \mu \mathrm{m}$ thin layers and stained with haematoxylin and eosin (H\&E). The stained tissue was examined and photographed with a Zeiss photomicroscope III.

All data obtained were subjected to the analysis of variance (ANOVA) and where differences existed, the results were further subjected to Duncan Multiple Range Test (DMRT) for means separation according to the procedures of SAS (1999).

\section{RESULTS}

Means squares from the analysis of variance (ANOVA) of biochemical indicators of nephrotoxicity in rabbits exposed to subchronic levels of crude oil are presented in Table I. Effects of treatment ( $T$ ) was highly significant $(\mathrm{P}<0.001)$ in alkaline phosphatase, significant $(\mathrm{P}<0.01)$ in creatinine and glucose. Effects of sex (S) was highly significant $\quad(\mathrm{P}<0.001) \quad$ in alkaline phosphatase while the interaction between treatment and sex $(T \times S)$ was highly significant $(\mathrm{P}<0.001)$ in urea and alkaline phosphatase $(\mathrm{P}<0.01)$.

TABLE 1: Mean squares from Analysis of Variance in biochemical repsonses in rabbits fed subchronic levels of crude oil

\begin{tabular}{llllllll}
\hline Source & DF & $\begin{array}{l}\text { Alkaline } \\
\text { Phosphatase }\end{array}$ & Urea & Creatanine & Glucose & $\begin{array}{l}\text { Total } \\
\text { Protein }\end{array}$ & Albumin \\
\hline Treatment (T) & 4 & $67.30^{* * * *}$ & $2.56^{*}$ & $1992.88^{* *}$ & $4.12^{* *}$ & $156.13^{*}$ & $33.58^{*}$ \\
Sex $(\mathrm{S})$ & 1 & $18605^{* * *}$ & $1.15 \mathrm{~ns}$ & $0.80 \mathrm{~ns}$ & $0.03 \mathrm{~ns}$ & $57.80 \mathrm{~ns}$ & $5.00 \mathrm{~ns}$ \\
T $\times \mathrm{S}$ & 4 & $37.30^{* * *}$ & $6.86^{* * *}$ & $650.18 \mathrm{~ns}$ & $4.07 \mathrm{~ns}$ & $77.43 \mathrm{~ns}$ & $18.38 \mathrm{~ns}$ \\
Error & 10 & 4.05 & 0.58 & 287.30 & 0.50 & 22.50 & 7.10 \\
Total & 19 & & & & & \\
$*$ & $=$ & $P<0.05$ & & & & \\
$* *$ & $=$ & $P<0.01$ & & & & \\
$* * *$ & $=$ & $P<0.001$ & & & & \\
Ns & $=$ & not significant & & & & & \\
\hline
\end{tabular}

TABLE II: Biochemical responses of rabbits exposed to subchronic levels of crude oil

\begin{tabular}{|c|c|c|c|c|c|c|}
\hline $\begin{array}{l}\text { Contamination } \\
\text { Level/treatment }\end{array}$ & $\begin{array}{l}\text { Alkaline } \\
\text { Phosphatase } \\
\text { (ImL) Mean } \pm \text { SEM }\end{array}$ & $\begin{array}{l}\text { Urea } \\
(\text { mmol/L) } \\
\text { Mean } \pm \text { SEM }\end{array}$ & $\begin{array}{l}\text { Creatinine } \\
(\text { umol/L) } \\
\text { Mean } \pm \text { SEM }\end{array}$ & $\begin{array}{l}\text { Glucose } \\
\text { (umol/L) } \\
\text { Mean } \pm \text { SEM }\end{array}$ & $\begin{array}{l}\text { Total } \\
\text { Protein }(\mathrm{g} / \mathrm{L}) \\
\text { Mean } \pm \text { SEM }\end{array}$ & $\begin{array}{l}\text { Albumin } \\
(\mathrm{g} / \mathrm{L}) \\
\text { Mean } \pm \mathrm{SEM}\end{array}$ \\
\hline $1: 0.00 \%$ & $.70^{6}$ & $5.40 \pm 1.13^{b}$ & $135.50 \pm 11.67^{\circ}$ & $5.23 \pm 0.27^{\mathrm{b}}$ & $38.50 \pm 5.19^{\circ}$ & $23.00 \pm 1.08^{b}$ \\
\hline II:0.05\% & $18.25 \pm 1.38^{\mathrm{hx}}$ & $36^{\mathrm{ah}}$ & $152.25 \pm 5.1 \mathrm{lb}^{\mathrm{c}}$ & $5.35 \pm 0.12^{b}$ & $40.50 \pm 1.19^{b c}$ & $23.25 \pm 2.32^{b}$ \\
\hline III: $0.10 \%$ & $19.25 \pm 0.48^{\mathrm{b}}$ & $6.45 \pm 0.19^{a b}$ & $158.50 \pm 6.56 b^{c}$ & $6.70 \pm 0.57^{\mathrm{a}}$ & $42.50 \pm 1.44^{b c}$ & $24.00 \pm 0.82^{b}$ \\
\hline IV:0.15\% & $23.75 \pm 1.18^{\mathrm{a}}$ & $7.43 \pm 0.52^{a}$ & $178.25 \pm 12.58^{b}$ & $7.44 \pm 0.40^{a}$ & $46.25 \pm 1.44^{b}$ & $24.25 \pm 1.44^{b}$ \\
\hline$V: 0.20 \%$ & $25.75 \pm 3.75^{a}$ & $7.23 \pm 1.08^{\mathrm{a}}$ & $191.50 \pm 9.61^{\mathrm{a}}$ & $7.08 \pm 1.11^{\mathrm{a}}$ & $54.25 \pm 3.43^{\mathrm{a}}$ & $30.00 \pm 1.78^{\mathrm{a}}$ \\
\hline
\end{tabular}

Within column, Meani-SEM with different superscript(s) differ significantly $(\mathrm{P}<0.05)$

Serial detcrmination of biochemical indicators of kidney damage showed that there was a progressive increase of metabolites with increasing concentration of crude oil. The data is presented in Table II. The mean concentration of alkaline phosphatase in the control animals was $15.75 \pm 1.38 \mathrm{IU} / \mathrm{L}$ and increased from 
$18.25 \pm 1.38 \mathrm{IU} / \mathrm{L}$ to $25.75 \pm 3.75 \mathrm{IU} / \mathrm{L}$ in the treated animals. Mean urea level was $5.40 \mathrm{mmo} / L$ in the control and increased from $6.45 \mathrm{mmo} / L$ to $7.43 \mathrm{mmo} / L$ in treated animals. Creatinine level was $135.50 \mathrm{mmo} / \mathrm{L}$ and increased from $152.25 \mathrm{mmo} / L$ to $191.50 \mu \mathrm{mol} / \mathrm{L}$. The mean values of glucose, total protein and albumin also increased with increasing dietary concentrations of crude oil.

The susceptibility to nephrotoxicity of mammals is attributed to the unique physiological and anatomic features of the kidney. Filtration processed by the kidneys involve concentrating potential toxicant in the tubular fluid. The increased concentration of biochemical indicators of kidney damage observed was confirmed by histological examination. A histological study of the kidney tissues revealed the presence of eosinophilic cast in the lumen of distal convoluted tubule (Fig 1a). Bowman's capsule was observed to be dilated and also contain some loose eosinophilic cast (Fig 1b). There was eosinophilia scattered in many other parts of the kidney (Fig $1 \mathrm{c}, \mathrm{d}$ ).
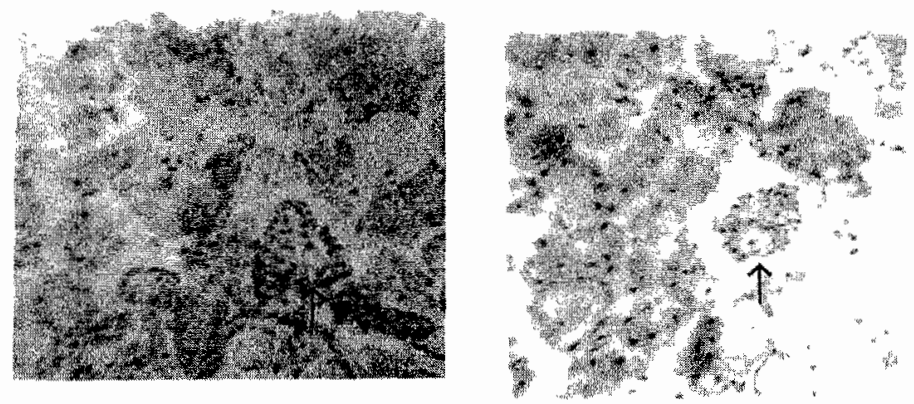

Plate la Eosinophilie (proteinaceous) cast in Plate 1 b. Dilated Bowmon's capsule contaning the lunen of distal convoluted tubules $\times 40$. loose eosinophulic casi.
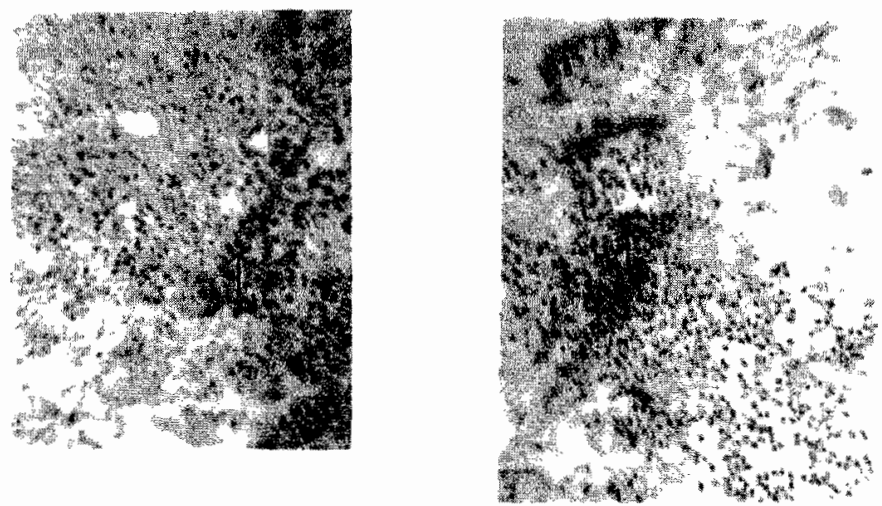

Plate $1 c, d$

Eosinophilia scattered in mary parts of the kidney $x 40$.

\section{DisCUSSION}

The functional integrity of the mammalian kidneys is vital to the total body homeostasis, as they play a principal role in the excretion of metabolic wastes and the regulation of extracellular fluid volume, electrolyte composition and acid-base 
balance. Evaluation of kidney function can be accomplished using a variety of methods (Foulkes, 1993; Davis and Berndt, 1994). From the method used the activities of ALP was seen to increase significantly $(P<0.05)$ with increasing concentration of crude oil. This enzyme is appropriated in large quantity in the brush borders. The presence of localized enzymes in the serum may reflect brush border damage.

Another important indicator of nephrotoxicity is blood urea and creatinine concentrations. These components were observed to increase with increasing concentration (Table 2). They are normally filtered by the glomerulus; therefore, increased serum concentrations suggest decreases in glomerular filtration rate (Counts et al., 1995). This finding is in consonance with the observations of Bach and Gregg (1985) and Barret (1994) where chemically induced nephrotoxicity resulted in reduced glomerular filtration rate culminating in increased concentrations of urea and creatinine.

Furthermore glucose, total protein and albumin levels were observed to increase. High glucose concentration as well as high molecular weight proteins such as albumin is suggestive of glomerular damage (Christensen and Nielson, 1991). However, specificity is often lacking in some of the non invasive assessment of overall renal functional integrity. Histopathologic evaluation of the kidney following treatment with chemical inducers is crucial in identifying site, nature and severity of the neprotoxic lesion.

The findings of the present study indicate that graded doses of crude oil in the diet caused nephrotoxicity in rabbits. Simple histological study of the kidney show the presence of eosinophilic cast in the lumen of distal convoluted tubules (Fig 1a). Furthermore, the Bowman's capsule is dilated and also contains some loose eosinophilic cast (Fig lb). Eosinophilia was also observed in many other sections of the kidney (Fig $1 \mathrm{c}$ and $1 \mathrm{~d}$ ). Various constituents of crude oil may initiate cellular injury by initiating toxicity due to its intrinsic reactivity with cellular macromolecules. Since crude oil is made up of hydrocarbons, metal and non-metal constituents, each reacts in its unique way with various components of the kidney. Monks et al., (1994) and Lau and Monks (1993) observed similar nephrotoxicity in mice dosed with bromobenzene, a hydrocarbon. They argued that like the halo-alkenes, the biotransformation of this compound is critical for the expression of nephrotoxicity. The biotransformation follows a series of conjugation which becomes a thousand folds more potent than the bromobenzene itself in producing nephrotoxicity. Again, heavy metals components in the crude oil may also cause toxicity through their ability to bind to sulphydryl group. For instance, mercury is known to produce nephrotoxicity by binding sulphydryl groups on cellular proteins. This effect has been associated with the greater degree of lipophilicity of organic mercury components (Conner and Fowler 1993, Zalups and Lash, 1994).

\section{CONCLUSION}

Crude oil seems to be a nephrotoxicant. The presence of eosimophilic cast in the lumen of distal convoluted tubules as well as the observed dilation of the bowman's capsule may lead to complete collapse of the kidney. These are indications of cellular injury which may eventually lead to cellular death. 


\section{NIGERIAN VETERINARY JOURNAL}

\section{REFERENCES}

BACH, P.H., and GREGG, N.J. (1985). Experimentally induced renal papillary necrosis and upper urothelial carcinoma. Int. Rev. Exp. Pathol., 5: 301-350.

BARRET, B.J. (1994). Contrast nephrotoxicity. J. Am. Soc. Nephrology, 5: 125-137.

BENDER, R.J.L. and MEAD, D.C. (1974). Evaluation of glucose-6phosphate-dehydrogenase from leuconostoc mesonteroides in the hexokinase method for determining glucose in serum. Clin. Chem., 31: 586-590.

CARLS, M.G., RICE, S.D. and HOSE, J.E. (1999). Sensitivity of fish embryos to weathered crude oil: Part 1 Low level exposure during incubation causes malformations, genetic damage and mortality in larval pacific herring (Clupea pullasi). Environ. Toxicol. Chem., 18: 481493.

CARLS, M.G., HOSE, J.E., THOMAS, R.E. and RICE, S.D. (2000). Exposure of pacific herring to weathered crude oil: Assessing effects on ova. Environ Toxicol Chem., 19: 1649-1659.

CHRISTENSEN, E.I. and NIELSON, S. (1991). Structural and functional features of protein handling in the proximal tubule. Sem. Nephrol., 11: 414-439.

COUNTS, R.S., NOWAKI, G., WYATT, R.D. and SCHELLMANN, R.G.
(1995). Nephrotoxicants inhibition of renal proximal tubule cell regeneration. Am. J. Physiol., 269: F274-F281.

CONNER, E.A. and FOWLER, B.A. (1993). Mechanisms of metal induced nephrotoxicity. In Hook, J.B., Goldstein, R.S. (ed). Toxicology of the kidney, 2nd Edition, New York Raven; pp.437457.

DAVIS, M.E. and BERNDT, W.O. (1994). Renal methods for toxicology. In Hayes, A.W. (ed). Principles and methods of Toxicology, 3rd Edition. New York: Raven pp.871-894.

DOUMAS, B.T. (1975). Biuret reaction for total protein measurement. Clin. Chem., 21: 1159-1166.

EISENWEINER, H.G. (1976). Kinetishe Bestimung des Hamstottes mit dem LKB-system. J. Clin. Chem. Clin. Biochem., 14: 261-264.

FABINY, D.L. and ERTINGHAUSEN, G. (1971). Antomated reaction rate method for determination of serum creatinine with the centrichem, Clin. Chem., 17: 696-700.

FOULKES, E.C. (1993). Functional assessment of the kidney. In: Hook, J.B., Goldstein, R.S. (eds) Toxicology of the kidney, 2nd Edition, New York: Raven pp.3760.

HALFKENSHEID, J.C.M. and KOHLER, B.E.M. (1986). Temperature conversion factors for four enzymes 
in commercial control sera. Clin. Chem., 32: 1616.

IMEVBORE, A.M.A. (1979). The impact of oil pollution on the biota of the Niger Delta. Seminar in Environmental aspects of oil pollution in the Niger Delta, Port Harcourt, Nigeria.

IMEVBORE, A.M.A. and ADEYEMI, S.A. (1981). Environmental and monitoring in relation to prevention and control of oil pollution. In Proceedings of the petroleum industry and Nigeria Environment. NNPC/FMNEH 9-12 Nov. 1981, PTI, Warri, Nigeria. P.135-142.

LAU, S.S. and MONKS, T.J. (1993). Nephrotoxicity of bromobenzene: The role of quinine thioethers In Hook, J.B., Goldstein, R.S. (eds). Toxicology of the kidney, 2nd Edition New York: Raven pp.415436.

McCAIN, B.B., HODGINS, H.O., GROULUND, W.D., HAWKES, J.W. BROWN, D.W., MYERS, M.S. and VANDERMEULEN, J.H. (1978). Bioavailability of crude oil from experimentally oiled sediments to English sole (Parophrys vetulus) and pathological consequences. $J$. Fish. Res. Board Can., 35:657-664.

MONKS, T.J., LO, H.H. and LAU, S.S. (1994). Oxidation and acetylation as determinants of 2-bromocystein sylhydroquinone mediated nephrotoxicity. Chem. Res. Toxicol., 7: 495-502.
NEFF, J.M., OSTAZESKI, S., GARDER, $W$. and STEISKAL, I. (2000). Effects of weathering on the toxicity of three offshore Australian crude oils and diesel fuel to marine mammals. Environ. Toxicol. Chem., 19: 809-820.

NGODIGHA, E.M., OLAYIMIKA, F.O., ORUWARI, B.M., EKWEOZOR, I.K.E. and WEKHE, S.N. (1999). Toxic effects of crude oil on organ weights and blood cells of West African Dwarf Goat. Nig. Vet. J., 20: 82-91.

PAYNE, J.F., KICENIUK, J., FANCEY, L.L., WILLİAM, U., FLETCHER, G.L. RAHIMTULA, A. and FOWLER, B. (1988). What is the safe level of polycyclic aromatic hydrocarbons for fish: subchronic toxicity study on winter flounder (Pseudopleuronectes americanus). Can. J. Fish Aquat. Sci., 45: 19831993.

SASTRY, N.S.R. and THOMAS, C.K. (1981). Farm animal management Vikas Publishing House PVT Ltd. $391 p$.

SAS, (1999). Statistical Analysis System, Users Guide, SAS/STAT; Version 8 Edition, SAS Institute Inc. Cary NC., USA.

SNOWDEN, R.J. and EKWEOZOR, I.K.E. (1987). The impact of minor oil spillage in the estuarine Niger Delta. Mar. Pollut. Bull., 18: 595-599.

THOMAS, R.E., RICE, S.D., BABCOCK, M.M. and MOLES, A. (1989). Differences in hydrocarbon uptake 


\section{NIGERIAN VETERINARY JOURNAL}

and mixed function oxidase activity between juvenile and spawning adult coho salmon (Oncorhynchus kisutch) exposed to cook inlet crude oil. Comp. Biochem. Physiol., 93C: 155-159.

TRUSCOTT, B., IDLER, D.R. and FLETCHER, G.L. (1992). Alterations of reproductive steroids of male winter flounder (Pseudopheuronectes americanus) chronically exposed to low levels of crude oil in sediments. Can. J. Fish. Aquid. Sci., 49: 2190-2195.

VIGNIER, V., VAUDERMEULEN, J.H. and FRASER, A.J. (1992). Growth and food conversion by Atlantic salmon parr 40 days exposure to crude oil. Trans. Am. Fish. Soc. 121: 322-332.

ZALUPS, R.K. and LASH, L.H. (1994). Advances in understanding the renal transport and toxicity of mercury. $J$. Toxicol. Environ. Health, 42: 1-4. 